\title{
Oral almitrine in treatment of acute respiratory failure and cor pulmonale in patients with an exacerbation of chronic obstructive airways disease
}

\author{
P A Bardsley, J Tweney, N Morgan, P Howard
}

\begin{abstract}
The effects of oral almitrine bismesylate, a respiratory stimulant that acts on peripheral arterial chemoreceptors, was studied in patients with chronic obstructive airways disease and hypoxaemic cor pulmonale. Twenty three patients admitted to hospital with an acute exacerbation of ventilatory failure were randomised to receive either almitrine $100 \mathrm{mg}$ twice a day reducing to $50 \mathrm{mg}$ twice a day over 48 hours or placebo in addition to conventional treatment. On admission the mean (SE) values for blood gas tensions were $\mathrm{PaO}_{2} 4 \cdot 8(0 \cdot 3)$ and $\mathrm{PaCO}_{2} 7 \cdot 7(0 \cdot 3) \mathrm{kPa}$ in the 12 patients who received almitrine and $\mathrm{PaO}_{2} 4.9(0 \cdot 1)$ and $\mathrm{PaCO}_{2} 7.6(0.3) \mathrm{kPa}$ in the 11 who received placebo. After three hours of oxygen therapy at $11 / \mathrm{min}$ there was a similar rise in $\mathrm{PaO}_{2}$ in both groups, $6.4(0.2) \mathrm{kPa}$ in those receiving almitrine and $6.6(0.4)$ $\mathrm{kPa}$ in those receiving placebo. After 24 hours of oxygen therapy values of $\mathrm{PaO}_{2}$ were again similar at $6.3(0.8) \mathrm{kPa}$ and 6.7 $(2 \cdot 2) \mathrm{kPa}$ respectively. Arterial blood gas tensions improved during the study in those who survived but no significant differences were apparent between the two groups. There were six deaths, five in the almitrine group and one in the placebo group. There were no differences between the groups in respiratory rate, results of spirometry, oxygen requirement, or degree of dyspnoea (on visual analogue scale). The results did not show any benefit from oral almitrine in patients with acute respiratory failure secondary to chronic obstructive airways disease. Plasma almitrine concentrations, however, were often below the optimum therapeutic range, suggesting impaired
\end{abstract}

mation is available on the effect of the drug in patients with an acute exacerbation of chronic bronchitis and emphysema associated with acute ventilatory failure.

In theory almitrine, like other respiratory stimulants, would be an attractive means of reducing the requirement for oxygen and of limiting excessive hypercapnia during low flow oxygen therapy. It has the advantage that it can be taken orally. There is some evidence that intravenous almitrine can improve arterial oxygen tensions in patients with chronic obstructive airways disease and acute ventilatory failure, ${ }^{4-6}$ but concern was expressed in one study because pulmonary artery pressure rose in all 12 patients, four of whom complained of malaise and increased dyspnoea. ${ }^{4}$ There are few studies of oral almitrine in patients with this condition and none has looked specifically at patients with hypoxaemic cor pulmonale. Patients with acute on chronic ventilatory failure given oral almitrine in a double blind study over two weeks did not show any improvement in blood gas tensions until day $10,{ }^{7}$ and in another study oral almitrine did not reduce the requirement for assisted ventilation. ${ }^{8}$

Whether almitrine has a useful role in the treatment of acute ventilatory failure secondary to chronic obstructive airways disease has not been established clearly, and whether the drug is associated with a more rapid recovery or, more importantly, a reduction in the appreciable mortality associated with this condition is not known. We examined the effect of oral almitrine on arterial blood gas tensions, inspired oxygen requirement, symptoms, and survival in patients with acute respiratory failure and hypoxaemic cor pulmonale secondary to an exacerbation of chronic obstructive airways disease.

Methods

PATIENTS

We studied 23 patients with chronic obstructive airways disease and hypoxaemic cor pulmonale admitted to hospital with an acute exacerbation of ventilatory failure. Patients were randomly allocated to receive oral almitrine or placebo in a double blind manner in addition to conventional treatment. The criteria for entry into the study were respiratory failure with arterial oxygen tension $\left(\mathrm{PaO}_{2}\right)$ less than $8.0 \mathrm{kPa}$ on admission to hospital and arterial carbon dioxide tension $\left(\mathrm{PaCO}_{2}\right)$ \footnotetext{
drug absorption.

Almitrine bismesylate is a recently developed respiratory stimulant that acts on peripheral chemoreceptors, principally of the carotid body, to increase tidal volume. ${ }^{1}$ It also causes pulmonary vasoconstriction and may have beneficial effects on ventilation or perfusion matching within the lung. ${ }^{2}$ Oral almitrine $100-200 \mathrm{mg}$ daily when taken for up to a year improves arterial blood gas tensions in patients with stable hypoxaemic chronic obstructive airways disease. ${ }^{3}$ Little infor-

Dr Bardsley, Depart

Respiratory Medicine,

Leicester LE3 9QP.

Accepted 29 March 1991

University
Department of
Medicine, Royal

Sheffield S10 2JF

P Howard

Fulmer Hall, Fulmer, Slough SL3 6HH

N Morgan
} 
greater than $6.0 \mathrm{kPa}$ while breathing room air; peripheral oedema on clinical examination; a forced expiratory volume in one second $\left(F_{1} V_{1}\right)$ less than 1.51 (recorded either in the past or when clinically stable); and a forced expiratory ratio $\left(\mathrm{FEV}_{1} /\right.$ forced vital capacity (FVC)) of less than $70 \%$. Patients with asthma, reversible airflow obstruction, interstitial pulmonary fibrosis, chest wall disorders, or neuromuscular disorders were excluded, as were those with clinically relevant cardiac, renal, or hepatic disease. No patients had received almitrine or any other respiratory analeptic within the previous two months.

\section{ASSESSMENT AND STANDARD TREATMENT}

On admission a clinical assessment was made and an arterial blood sample taken. If the patient had received oxygen the arterial sample was taken after this had been stopped for at least 30 minutes. If the entry criteria were fulfilled informed consent was obtained and the patient entered into the study. A venous blood sample was taken for standard haematological and biochemical testing, chest radiography and electrocardiography were performed, and sputum was sent for microbiological analysis. All patients were then scored on a visual analogue scale $(0-100 \mathrm{~mm})$ for sense of wellbeing and degree of breathlessness (for wellbeing $0=$ feeling ill, $100=$ feeling well; for breathlessness $0=$ not breathless, $100=$ extremely short of breath).

Oxygen was given initially at a flow rate of $1 \mathrm{l} / \mathrm{min}$ through nasal cannulas, and oral almitrine $100 \mathrm{mg}$ or placebo was then given. All patients were treated in the standard way with chest physiotherapy, an antibiotic (usually amoxycillin $500 \mathrm{mg}$ three times a day or trimethoprim or erythromycin if the patient was allergic to penicillin), intravenous salbutamol $(10 \mathrm{mg}$ in $50 \mathrm{ml}$ of physiological saline infused over 24 hours), and diuretics (oral frusemide $80 \mathrm{mg}$ and spironolactone $100 \mathrm{mg}$ daily). After three hours a venous

Table 1 Characteristics of patients randomly allocated to receive almitrine or placebo (mean (SE) values)

\begin{tabular}{|c|c|c|}
\hline Characteristic & $\begin{array}{l}\text { Patients receiving } \\
\text { almitrine } \\
(n=12)\end{array}$ & $\begin{array}{l}\text { Patients receiving } \\
\text { placebo } \\
(n=11)\end{array}$ \\
\hline Age (y) & $65 \cdot 0(2 \cdot 0)$ & $72 \cdot 0(2 \cdot 0)^{\star}$ \\
\hline $\operatorname{Sex}(\mathbf{M} / \mathbf{F})$ & $6 / 6$ & $8 / 3$ \\
\hline Weight (kg) & $58 \cdot 0(6 \cdot 0)$ & $59 \cdot 0(5 \cdot 0)$ \\
\hline \multicolumn{3}{|l|}{$\mathrm{PaO}_{2}(\mathrm{kPa}):$} \\
\hline Initial & $4 \cdot 8(0 \cdot 3)$ & $4.9(0.3)$ \\
\hline After three hours & $6 \cdot 4(0 \cdot 2)$ & $6 \cdot 6(0.4)$ \\
\hline \multicolumn{3}{|l|}{$\mathrm{PaCO}_{2}(\mathrm{kPa}):$} \\
\hline Initial & $7 \cdot 7(0 \cdot 3)$ & $7 \cdot 6(0 \cdot 3)$ \\
\hline After three hours & $8 \cdot 1(0 \cdot 3)$ & $8.8(0.5)$ \\
\hline \multicolumn{3}{|l|}{$\mathrm{H}^{+}$concentration $(\mathrm{nmol} / \mathrm{l})$ : } \\
\hline Initial & $44 \cdot 0(1 \cdot 0)$ & $43 \cdot 0(1 \cdot 0)$ \\
\hline After three hours & $43.0(1.0)$ & $46.0(2 \cdot 0)$ \\
\hline $\mathrm{FEV}_{1}(\mathrm{l})$ & $0.43(0 \cdot 1)$ & $0 \cdot 40(0 \cdot 1)$ \\
\hline FVC (1) & $1.08(0.23)$ & $0.97(0.29)$ \\
\hline Respiratory rate (breaths/min) & $27 \cdot 0(3 \cdot 0)$ & $28 \cdot 0(3 \cdot 0)$ \\
\hline Visual analogue score for dyspnoea (mm) & $56 \cdot 0(11 \cdot 0)$ & $43.0(8.0)$ \\
\hline Visual analogue score for wellbeing (mm) & $33.0(9.0)$ & $44.0(7 \cdot 0)$ \\
\hline Packed cell volume & $49 \cdot 0(2 \cdot 0)$ & $43.0(2 \cdot 0)$ \\
\hline
\end{tabular}

${ }^{*} \mathrm{p}<0.05$.

$\mathrm{PaO}_{2}$-arterial oxygen tension; $\mathrm{PaCO}_{2}$-arterial carbon dioxide tension; $\mathrm{FEV}_{1}$ - forced expiratory volume in one second; $\mathrm{FVC}$-forced vital capacity. blood sample was taken to determine the plasma almitrine concentration and a further arterial sample taken. If the $\mathrm{PaCO}_{2}$ had decreased or remained constant the inspired oxygen flow rate was increased to $1.5 \mathrm{l} / \mathrm{min}$, if it had increased by less than $1 \mathrm{kPa}$ the oxygen flow rate was left at $1.0 \mathrm{l} / \mathrm{min}$, and if it had increased by more than $1 \mathrm{kPa}$ the flow rate was reduced to $0.5 \mathrm{l} / \mathrm{min}$. Blood was taken for estimation of the plasma almitrine concentration at five, eight, and 12 hours. Arterial blood gas tensions were rechecked again after 24 hours of treatment and as indicated clinically.

\section{DRUG TREATMENT}

Almitrine was given $100 \mathrm{mg}$ twice daily with food for 24 hours followed by $100 \mathrm{mg}$ in the morning and $50 \mathrm{mg}$ in the evening for a further 24 hours and $50 \mathrm{mg}$ twice daily with food for the next 18 days. Patients received chest physiotherapy twice daily and were not allowed to smoke. Fluid intake was initially restricted to 1 litre per day; the diuretics were continued for the duration of the trial. When the $\mathrm{PaO}_{2}$ had risen above $8 \mathrm{kPa}$ for 24 hours the intravenous infusion of salbutamol was stopped and this drug was given by nebuliser ( $5 \mathrm{mg} / 5 \mathrm{ml}$ four times a day). Antibiotic treatment was continued for 10 days. Other drug treatment on admission, including any corticosteroids, was continued unchanged.

\section{MONITORING OF PATIENTS}

The study was continued for three weeks. Patients were assessed each morning and arterial blood gas tensions checked before almitrine was given. Inspired oxygen concentration was adjusted to try to maintain $\mathrm{PaO}_{2}$ at around $8 \mathrm{kPa}$. Respiratory rate, results of spirometry, and visual analogue scores were recorded daily during the first week and then on alternate days. On these days the oxygen flow rate was also checked with a rotameter. On days $2,4,7,14$, and 21 venous blood samples were taken for estimation of the blood count and electrolyte and plasma almitrine concentrations. Blood samples were taken two to three hours after administration of almitrine, when peak plasma concentrations would be expected. ${ }^{9}$ At the end of the study arterial blood gas tensions were recorded with the patient breathing air after having stopped receiving oxygen for at least four hours.

All arterial blood samples were analysed immediately with a Corning 170 machine and spirometry was performed with a portable spirometer (Micro Medical Instruments). Plasma almitrine concentrations were measured by gas-liquid chromatography to a sensitivity of $5 \mathrm{ng} / \mathrm{ml}^{10}$ The study was approved by the hospital ethics committee.

\section{STATISTICAL ANALYSIS}

Patients withdrawn from the study were included in the analysis. Mean values and standard errors (SE) of measurements are given. Measurements on entry into and during the study were compared between and within groups with a paired or unpaired Student's $t$ test as appropriate. Survival be- 
Table 2 Details of six patients who died during study

\begin{tabular}{|c|c|c|c|c|c|c|c|c|c|}
\hline \multirow{2}{*}{$\begin{array}{l}\text { Age } \\
(y)\end{array}$} & \multirow{2}{*}{$\begin{array}{l}\operatorname{Sex} \\
(M / F)\end{array}$} & \multirow{2}{*}{$\begin{array}{l}\text { Receiving } \\
\text { almitrine } \\
\text { or placebo }\end{array}$} & \multicolumn{2}{|c|}{$\begin{array}{l}\text { Blood gas tensions on } \\
\text { admission }(\mathrm{kPa})\end{array}$} & \multicolumn{2}{|c|}{$\begin{array}{l}\text { Blood gas tensions within } \\
24 \text { hours after death }(\mathrm{kPa})\end{array}$} & \multirow{2}{*}{$\begin{array}{l}\text { Oxygen } \\
\text { flow rate } \\
\text { (l/min) }\end{array}$} & \multirow{2}{*}{$\begin{array}{l}\text { Day of } \\
\text { death }\end{array}$} & \multirow[b]{2}{*}{ Further details } \\
\hline & & & $\mathrm{PaO}_{2}$ & $\mathrm{PaCO}_{2}$ & $\mathrm{PaO}_{2}$ & $\mathrm{PaCO}_{2}$ & & & \\
\hline 68 & $\mathbf{M}$ & Almitrine & $4 \cdot 3$ & $7 \cdot 3$ & $4 \cdot 6$ & $8 \cdot 3$ & $1 \cdot 0$ & 5 & $\begin{array}{l}\text { Haemophilus influenzae infection } \\
\text { Severe emphysema at postmortem } \\
\text { examination }\end{array}$ \\
\hline 74 & $\mathbf{F}$ & Almitrine & 4.9 & $8 \cdot 8$ & $5 \cdot 2$ & $9 \cdot 2$ & 1.5 & 2 & $\begin{array}{l}\text { Died in respiratory failure } \\
\text { No postmortem examination }\end{array}$ \\
\hline 68 & $\mathbf{M}$ & Almitrine & $5 \cdot 9$ & $7 \cdot 2$ & $5 \cdot 5$ & $8 \cdot 0$ & $2 \cdot 0$ & 3 & $\begin{array}{l}\text { Died in ambulance during transfer } \\
\text { to intensive therapy unit } \\
H \text { influenzae infection } \\
\text { Severe emphysema at postmortem } \\
\text { examination }\end{array}$ \\
\hline 68 & $\mathbf{F}$ & Almitrine & $3 \cdot 6$ & $8 \cdot 1$ & $7 \cdot 2$ & $10 \cdot 4$ & $1 \cdot 0$ & 7 & $\begin{array}{l}\text { Grand mal convulsion } \\
\text { Subsequent respiratory arrest } \\
\text { No postmortem examination }\end{array}$ \\
\hline 71 & $\mathbf{M}$ & Almitrine & $4 \cdot 0$ & $6 \cdot 2$ & $7 \cdot 1$ & $8 \cdot 2$ & $1 \cdot 0$ & 3 & $\begin{array}{l}\text { Sudden cardiorespiratory arrest } \\
\text { Severe emphysema at postmortem } \\
\text { examination }\end{array}$ \\
\hline 77 & $\mathbf{M}$ & Placebo & $5 \cdot 8$ & $6 \cdot 8$ & $4 \cdot 2$ & $10 \cdot 2$ & 0.5 & 2 & $\begin{array}{l}\text { Treated with doxapram } \\
\text { Subsequent respiratory arrest } \\
\text { Severe emphysema and } \\
\text { widespread coronary artery disease } \\
\text { at postmortem examination }\end{array}$ \\
\hline
\end{tabular}

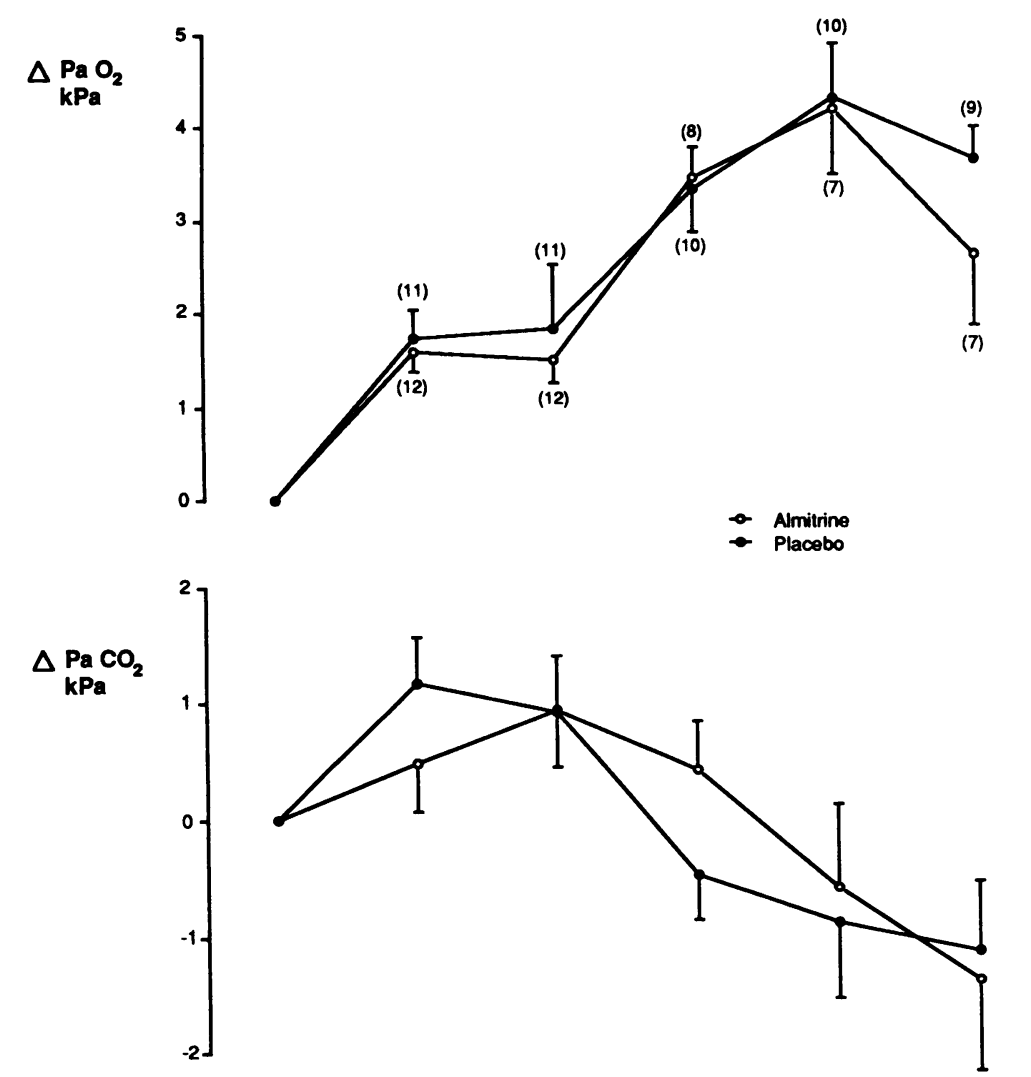

tween the groups was compared by Fisher's exact probability test.

\section{Results}

We studied 23 patients (14 men and nine women; age 51-82 years) with severe airflow obstruction $\left(\mathrm{FEV}_{1} 0 \cdot 21-1 \cdot 111\right)$ and ventilatory failure (on admission to hospital arterial blood gas tensions breathing air were $\mathrm{PaO}_{2} 3 \cdot 2-6 \cdot 7$ $\mathrm{kPa}$ and $\mathrm{PaCO}_{2} 6 \cdot 2-10 \cdot 0 \mathrm{kPa}$ ). Twelve patients were treated with almitrine and 11 with placebo. Table 1 shows the patients' characteristics on entry to the study.

Treatment was well tolerated and no patient complained of any symptom that could be attributed to the drug. Seventeen patients completed the study. No patient was withdrawn owing to side effects of the drug. Six patients died, five of those receiving almitrine and one receiving placebo. Details of the deaths are given in table 2 . The difference in death rate between the two groups was not significant $(\mathrm{p}=0.09)$.

There were no significant differences in arterial blood gas tensions or oxygen flow rates. After three hours of oxygen at $1 \mathrm{l} / \mathrm{min}$ the mean $\mathrm{PaO}_{2}$ had risen from 4.8 (0.3) to $6.4(0.2) \mathrm{kPa}$ in those receiving almitrine and from $4.9(0 \cdot 1)$ to $6.6(0.4) \mathrm{kPa}$ in those receiving placebo. After 24 hours of oxygen therapy mean values were $6.3(0.8) \mathrm{kPa}$ and $6.7(2.2) \mathrm{kPa}$ respectively. Figure 1 shows the mean changes in both $\mathrm{PaO}_{2}$ and $\mathrm{PaCO}_{2}$ from baseline over time.

Arterial blood gas tensions improved during the study and after three weeks mean arterial blood gas tensions when patients were breathing air were $\mathrm{PaO}_{2} 7 \cdot 1(0.83) \mathrm{kPa}, \mathrm{PaCO}_{2} 6 \cdot 0$ (0.5) $\mathrm{kPa}(\mathrm{n}=7)$ in those receiving almitrine and $\mathrm{PaO}_{2} 8 \cdot 1(0.5) \mathrm{kPa}, \mathrm{PaCO}_{2} 6.5(0.5) \mathrm{kPa}(\mathrm{n}=10)$ in those receiving placebo. Figure 2 gives the mean $\mathrm{FEV}_{1}, \mathrm{FVC}$, and respiratory rate and figure 3 gives the mean visual analogue scores for breathlessness and wellbeing. There were no significant differences between the two groups for any of these measurements. Table 3 gives the mean plasma almitrine concentrations

Figure 1 Mean changes in $\mathrm{PaO}_{2}$ and $\mathrm{PaCO}_{2}$ at 3 hours and on days 2, 7, 14, and 21 for patients treated with almitrine or placebo. The numbers of patients are in parentheses. All values were obtained with the patient breathing oxygen; the mean inspired oxygen flow rates are given (bottom). Bars indicate standard errors. in those receiving the drug. 

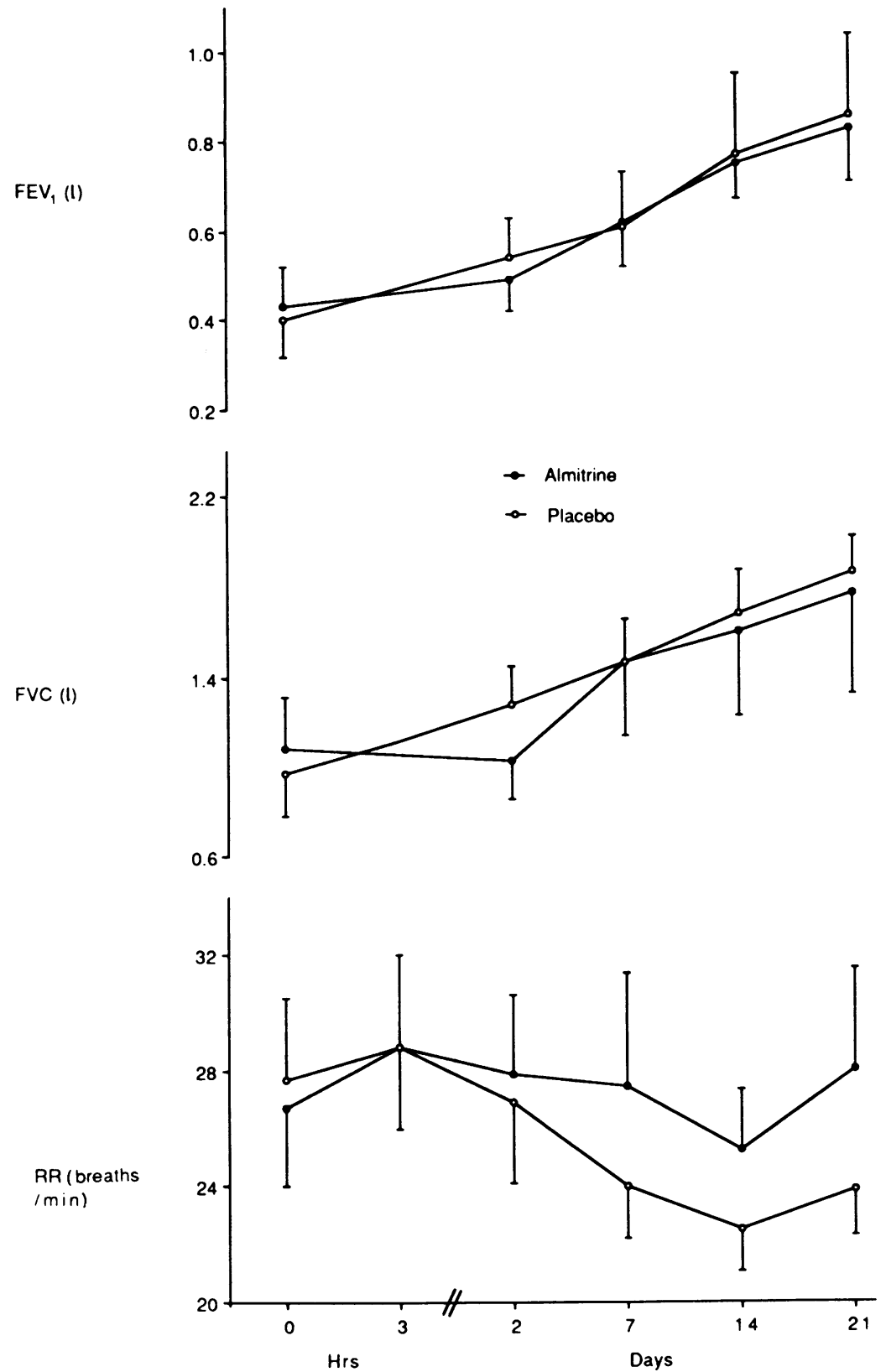

Figure 2 Mean values for forced expiratory volume in one second $\left(F E V_{1}\right)$, forced vital capacity $(F V C)$, and respiratory rate $(R R)$ for patients treated with almitrine or placebo. Bars indicate standard errors.

\section{Discussion}

Patients with acute ventilatory failure secondary to an exacerbation of chronic obstructive airways disease are treated initially with controlled oxygen. If an acceptable $\mathrm{PaO}_{2}$ cannot be achieved without incurring excessive hypercapnia with worsening respiratory acidosis assisted ventilation must be considered. The difficulties of weaning such patients from assisted ventilation are widely recognised and so many patients are treated with the respiratory stimulant doxapram by intravenous infusion while other treatment starts to take effect. The non-specific arousal produced by doxapram often limits its use. Almitrine offers a different therapeutic approach and has the advantages of being active when taken orally and having no central side effects. However, the use of respiratory stimulants in patients with acute ventilatory failure is controversial. They are often prescribed on the assumption that central respiratory drive is insufficient, yet it is often increased in patients with acute ventilatory failure. ${ }^{11}$ Concern has also been expressed about respiratory analeptics worsening dyspnoea and exacerbating respiratory muscle fatigue. Nasal intermittent positive pressure ventilation may be helpful for these patients in the future. ${ }^{12}$

We assessed the effect of oral almitrine in patients with acute on chronic ventilatory failure and cor pulmonale secondary to chronic bronchitis and emphysema. All patients had severe, irreversible airflow obstruction. Patients treated with almitrine were well matched with those given placebo and all patients were treated in a standard manner with controlled oxygen, bronchodilators, chest physiotherapy, diuretics, and antibiotics.

Our regimen for giving controlled oxygen therapy was designed to try to standardise patient management as far as possible. The inspired oxygen was titrated to try to achieve a $\mathrm{PaO}_{2}$ above $8 \mathrm{kPa}$. However, a lower $\mathrm{PaO}_{2}$ was accepted if hypercapnia or respiratory acidosis worsened. In the first 24 hours seven patients treated with almitrine (three of whom subsequently died) and four treated with placebo had a $\mathrm{PaO}_{2}$ while breathing oxygen of less than $6.7 \mathrm{kPa}$, mainly because of worsening hypercapnia. $\mathrm{A} \mathrm{PaO}_{2}$ greater than $8 \mathrm{kPa}$ was often not achieved until days five to seven. Monitoring the degree of acidosis rather than the absolute $\mathrm{PaCO}_{2}$ might have been a better guide to oxygen requirement. ${ }^{13}$ Six patients, three in each group, became acidotic during oxygen therapy with a hydrogen ion concentration greater than $55 \mathrm{nmol} / 1$ (two of these patients died). There was no evidence that almitrine allowed a higher inspired oxygen concentration to be tolerated. No differences in oxygen flow rates between the groups were apparent at any stage. $\mathrm{FEV}_{1}$ and FVC were virtually the same in the two groups and improved in both over time. The $\mathrm{PaO}_{2}$ rose and $\mathrm{PaCO}_{2}$ fell progressively apart from during the initial worsening of hypercapnia. The respiratory rate was higher in the patients treated with almitrine. Breathlessness was more difficult to assess, but those given almitrine had a higher symptomatic score throughout the study. There was no correlation between the degree of dyspnoea and plasma almitrine concentration. Overall, wellbeing did not differ between the two groups.

Acute ventilatory failure in patients with chronic bronchitis and emphysema is associated with a high mortality. Six of the 23 patients $(26 \%)$ entered into the study died: five of those given almitrine and one of those given

Table 3 Mean (SE) plasma almitrine concentrations for the 12 patients treated with the drug at entry $\left(T_{o}\right)$ and at intervals thereafter

\begin{tabular}{lllllllllll}
\hline & $T_{0}$ & $3 h$ & $5 h$ & $8 h$ & $12 h$ & Day 2 & Day 4 & Day 7 & Day 14 & Day 21 \\
\hline Mean $(\mathrm{SE})$ almitrine concentration $(\mu \mathrm{g} / \mathrm{l})$ & $0(0)$ & $150(35)$ & $113(22)$ & $153(82)$ & $209(88)$ & $90(38)$ & $127(44)$ & $95(30)$ & $156(38)$ & $213(48)$ \\
\hline
\end{tabular}



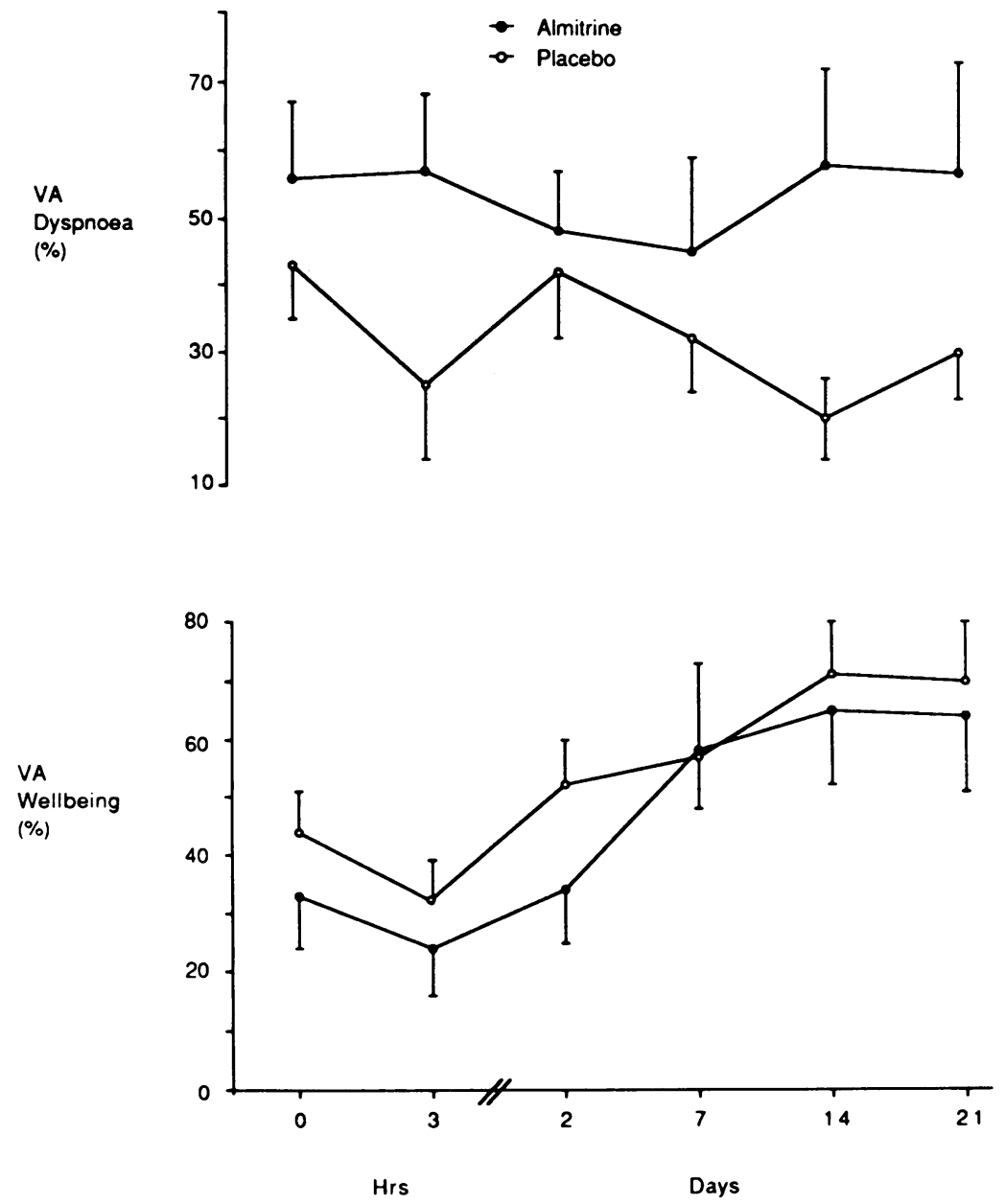

Figure 3 Visual analogue (VA) scores for breathlessness and wellbeing on a 0-100 $\mathrm{mm}$ scale $(0=$ not breathless and $100=$ extremely short of breath) and for wellbeing $(0=$ feeling ill and $100=$ feeling well $)$. Values are means with standard errors. hypoxaemia, pre-existing pulmonary hypertension, and change in $\mathrm{PaCO}_{2} .{ }^{14}{ }^{15}$ Although we did not measure pulmonary artery pressure, cor pulmonale was not more difficult to control in the surviving patients receiving almitrine. Further studies are needed to address this question.

The disappointing effect of almitrine on arterial blood gas tensions may be owing to low therapeutic drug concentrations. Despite a large initial dose, plasma almitrine concentrations were still below the optimum therapeutic range of $200-300 \mu \mathrm{g} / 1$ in most patients until day 14. A therapeutic plasma almitrine concentration was reached at 12 hours in seven patients but was not sustained. Only one patient had acceptable concentrations throughout the study. Almitrine is usually well absorbed; the slow rise in blood concentrations suggests impaired absorption, probably due to severe hypoxaemia and oedema of the bowel wall affecting gastrointestinal function. The bioavailability of oral almitrine is about $70 \%$ of that of an intravenous dose, and the pharmacokinetics in patients with chronic obstructive airways disease do not differ appreciably from those in healthy subjects. ${ }^{16}$ Higher oral doses could be tried, but in stable patients doses above $100 \mathrm{mg}$ a day tend to be associated with a high incidence of side effects such as nausea, abdominal discomfort, headache, and flushing. ${ }^{17}$ We did not find any significant correlation between arterial blood gas tensions and plasma almitrine concentrations.

Our results do not show any beneficial effects of oral almitrine in the treatment of acute ventilatory failure and cor pulmonale secondary to chronic obstructive airways disease. For the present this drug is better suited to the treatment of chronic than of acute respiratory failure.

We thank Servier Laboratories (United Kingdom) for measuring blood almitrine concentrations.

placebo. The deaths occurred in elderly patients with severe disease and poor quality of life, and in most of these cases a decision not to proceed with assisted ventilation had already been made. Two patients were withdrawn from the study just before death. One patient receiving placebo was treated unsuccessfully with intravenous doxapram and one receiving almitrine died during transfer to another hospital for assisted ventilation. Of the patients who died, three had achieved a $\mathrm{PaO}_{2}$ greater than $6.7 \mathrm{kPa}$ on treatment before terminal deterioration in arterial blood gas tensions. In the other three patients adequate oxygenation was limited by worsening hypercapnia (peak $\mathrm{PaCO}_{2}$ 9.1-11.0 kPa), although none had a hydrogen ion concentration above $55 \mathrm{nmol} / 1$ litre.

Although numbers in this study were small, there was no suggestion that almitrine improves survival, and it may have had an adverse effect. This adverse effect might be caused by an acute rise in pulmonary arterial pressure. Previous studies of acute administration of both oral and intravenous almitrine have shown a correlation between the rise in pulmonary artery pressure and the degree of
1 Laubie $M$, Schmitt $H$. Long lasting hyperventilation induced by almitrine: evidence for a specific effect on carotid and thoracic chemoreceptors. Eur J Pharmacol 1980;61:125-36.

2 Bee D, Gill GW, Emery CJ, Salmon GL, Evans TW, Barer GR. Action of almitrine on the pulmonary vasculature in ferrets and rats. Bull Eur Physiopathol Respir 1983; 19:539-45.

3 Voisin C, Howard P, Ansquer JC. Almitrine bismesylate: a long-term placebo-controlled double-blind study in COAD. Bull Eur Physiopathol Respir 1987;23(suppl 11): 169-82.

4 Naeue R, Melot C, Mols P, Hallemans R, Naeue N, Cornial $A$, Sergysels R. Effects of almitrine in decompensated chronic respiratory insufficiency. Bull Eur Physiopathol Respir 1981;17:153-61.

5 Tenaillon A, Labrousse J, Longchal J. Effects of almitrine on blood gases in chronic obstructive pulmonary disease (COPD) with acute respiratory failure [abstract]. Bull Eur Physiopathol Respir 1980;16:241P.

6 Touaty E, Viau F, Pariente R. A therapeutic trial of intravenous almitrine in acute exacerbations of chronic obstructive respiratory failure. Rev Fr Mal Respir

7 Neukirch F, Castilon Du Perron M, Verdier F, Drutel P, Legrand $M$, Botto $M J$, Lesobre $R$. Action d'un stimulant ventilatoire (S2620) administré oralement dans les bronchopneumopathies obstructives. Bull Eur Physiopathol Respir 1974;10:793-800. 1980:211-5. 
8 Lampropoulos S, Chatzipappas M, Tsekos GR, Tsantoulis $K$. The role of almitrine bismesylate in acute respiratory failure. Eur J Res Dis 1986;69(suppl 146):657-61.

9 Aubert Y, Baune A, Courte S, Gallaudeux J. Pharmacocinatique du bismesylate d'almitrine chez l'homme. Correlations entre les taux plasmatiques et les effets pharmacodynamiques. Bull Eur Physiopathol Respir 1982;18(suppl 4):307-14.

10 Baune A, Bromet N, Courte S, Voisin C. Trace determination of almitrine in plasma by gas-liquid chromatography using a nitrogen phosphorus detector. J Appl Chromatogr Biomed 1981;223:219-24.

11 Derenne J, Fleury B, Pariente R. Acute respiratory failure of chronic obstructive pulmonary disease. Am Rev Resp Dis 1988;138:1006-33.

12 Elliott MW, Steven MH, Philips GD, Branthwaite MA. Non-invasive mechanical ventilation for acute respiratory failure, $B M J 1990 ; 300: 358-60$.

13 Warren PM, Flenley DC, Millar JS, Avery A. Respiratory failure revisited: acute exacerbations of chronic bronchitis between 1961-68 and 1970-76. Lancet 1980;i:467-71.

14 Dull WL, Polu JM, Sadoul P. The pulmonary haemodynamic effects of almitrine infusion in men with chronic hypercapnia. Clin Sci 1983;64:25-31.

15 MacNee $\mathbb{W}$, Connaughton JJ, Rhind GB, Hayhurst MD, Douglas NJ, Muir AL, Flenley DC. A comparison of the effects of almitrine or oxygen breathing on pulmonary arterial pressure and right ventricular ejection fraction in hypoxic chronic bronchitis and emphysema. Am Rev Resp Dis 1986;134:559-65.

16 Bromet N, Singlas E. Pharmacokinetique clinique du bismesylate d'almitrine. Presse Medicale 1984;13:2071-7.

17 Tweney J. Almitrine bismesylate: current status. Bull Eur Physiopathol Respir 1987;23(suppl 11):156-63. 